\begin{tabular}{|c|c|c|}
\hline \multirow{3}{*}{$\begin{array}{l}\text { EREM 75/2 } \\
\text { Journal of Environmental Research, } \\
\text { Engineering and Management } \\
\text { Vol. } 75 \text { / No. } 2 \text { / } 2019 \\
\text { pp. 60-73 } \\
\text { DOl 10.5755/j01.erem.75.2.21300 }\end{array}$} & \multicolumn{2}{|c|}{$\begin{array}{l}\text { Modelling and Interpretation of Channel Profile Anomalies } \\
\text { through Stream Length Gradient (SL) Indexes and GIS: A Case } \\
\text { Study from the Vamanapuram River, Kerala, India }\end{array}$} \\
\hline & Received 2018/07 & Accepted after revision 2019/03 \\
\hline & \multicolumn{2}{|c|}{ crossef http://dx.doi.org/10.5755/j01.erem.75.2.21300 } \\
\hline
\end{tabular}

\title{
Modelling and Interpretation of Channel Profile Anomalies through Stream Length Gradient (SL) Indexes and GIS: A Case Study from the Vamanapuram River, Kerala, India
}

\section{H. Vijith*}

Department of Applied Geology, Faculty of Engineering and Science, Curtin University Malaysia, CDT 250, Miri 98009, Sarawak, Malaysia

\section{Prasannakumar}

Inter University Centre for Geospatial Information Science and Technology, University of Kerala, Kariavattom,

Thiruvananthapuram, Kerala, India

\section{P. Pratheesh}

Department of Geology, School of Earth Science Systems, Central University of Kerala, Kasaragod, Kerala, India

*Corresponding author: vijithh@gmail.com

A longitudinal profile of the Vamanapuram River and its five major tributaries was characterised to detect anomalies in terms of knick points through the calculation of stream length gradient (SL) indexes. Longitudinal profiles show presence of knick points in different reaches, indicating changes from a graded smooth concave profile to an ungraded convex profile. The ungraded profile segments were confirmed by high SL indexes having sudden changes in values than the adjacent segments and those exactly fitted with the ungraded profile 
segments. The $S L$ anomaly index is capable of expressing the stream profile anomalies in terms of its severity and to classify the river segments into different orders of anomalies. Higher order SL anomalies are mostly in the midland and lower regions rather than the headwaters region, are in uniform lithology and are unrelated to the map-scale structural features present in the river basin. The present study points to a differential effect of the geological process in the middle and lower reaches of the watershed in which the tributaries responded more than the major river. Past seismic events in the region confirm the role of neotectonic processes, which might have influenced the streams by changing the graded base level. Detailed field investigations of anomalous stream segments can help to identify and understand the imprints caused due to neotectonic activity.

Keywords: longitudinal profile, SL index, anomaly, Vamanapuram, India.

\section{Introduction}

Morphometric analysis of drainage basins, using well-defined mathematical relationships derived from the drainage/streams, reveals catchment characteristics in a quantitative manner and appraises the geological configuration and its control over the aerial, linear and relief characteristics of the basin (Horton, 1932, 1945; Strahler, 1952, 1957, 1964; Miller, 1953; Schumm, 1956, 1963). Advancement in the high-end computing technology and advent of Geographical Information System (GIS) tools have made morphometric analysis easier, resulting in numerous investigations in different drainage basins (Nag, 1998; Biswas et al., 1999; Mesa, 2006; Ajibade et al., 2010; Malik et al., 2011; Singh et al., 2013; Yunus et al., 2014; Sujatha et al., 2015; Matoš et al., 2016). Geomorphic indices, invented to overcome the limitations of traditional morphometric analysis in examining the tectonic influence over the drainage basins and streams, have gained wide application in recent times. Geomorphic indices are capable of identifying or differentiating the response of stream and drainage basins to the tectonic processes operated in the region. The more frequently used geomorphic indices are drainage basin shape, drainage basin asymmetry, transverse symmetric factor, hypsometric integral and curve, mountain front sinuosity, valley floor width to valley height ratio, longitudinal profile, stream length gradient index, steepness index and concavity index (Keller, 1986; Keller and Pinter, 2002; Pedrera et al., 2009; Dehbozorgi et al., 2010; Figueroa and Knott, 2010; Mahmood and Gloaguen, 2012; Bhat et al., 2013; Ahmad et al., 2014; Ntokos et al., 2016). Although a number of geomorphic indices are available, the basic analysis of longitudinal profiles and stream length gradient $(\mathrm{SL})$ indexes of the streams is considered as more important to evaluate the response of streams to lithological variations and tectonic influences. This is because the longitudinal profiles and SL indexes are capable of expressing changes in the base level, caused due to geological and geomorphological processes, through the changes in the gradational concave characteristics of the profile, either as convexity or upwelling and stepped nature.

Analysis of the stream pattern and channel characteristics, in order to understand geomorphic evolutional history of the streams and the basin, has gained wide attention in the recent times due to the availability of higher resolution digital elevation models and ready to derive geomorphic index modules in the GIS (Dhont and Chorowicz, 2006; Pérez-Peña et al., 2010; Trevisani et al., 2010; Viveen et al., 2012; Antón et al., 2014, Chang et al., 2015; Cheng et al., 2016; Aram and Arian, 2016). Although detailed studies are plenty as reported from different parts of the world, only limited attempts have been in India to understand the geomorphic characteristics of the river basins, using geomorphic indices (Kale and Shejwalkar, 2008; Joshi et al., 2013; Dar et al., 2014; Kale et al., 2014; Roy and Sahu, 2015; Bhattacharjee et al., 2016; Borgohain et al, 2016; Kothyari et al., 2016; Prizomwala et al., 2016; Vijith et al., 2016). Among this majority, most of such studies are from the extra-Peninsular India and Indo-Gangetic alluvial plains rather than the rivers in Peninsular India. In Peninsular India, the east 
flowing rivers are of a bigger size compared with the west flowing ones, although the majority originate from east and west sides of the Western Ghats. In the present study, a west flowing river (Vamanapuram River) which originates from the southernmost part of the Western Ghats in Kerala, India, and draining into the Arabian Sea was selected to analyse the channel characteristics. The Vamanpuram River basin has been studied in terms of morphometric analysis, hypsometric analysis, longitudinal profile with land use pattern, groundwater potential mapping, recharge site identification, land use/land cover mapping and water quality analysis (Joji et al., 2001; Chattopadhyay et al., 2006; Ajin et al., 2013; Joji and Nair, 2014). However, no attempt has so far been made to understand the channel characteristics of the Vamanapuram River in terms of channel anomalies related to neotectonic events that occurred in the basin. The critical analyses of longitudinal profiles and the stream length gradient (SL) indexes are found to be more effective in detecting the channel anomalies and differentiating the causes (Troiani and Della Seta, 2008; Font et al., 2010;
Martinez et al., 2011; Della Seta et al., 2012; Moussi et al., 2018). In view of this, the present study intends to make an extended use of longitudinal profiles and SL indexes in identifying and quantifying the anomalies present in the Vamanapuram River and its five major tributaries, which will provide insight into the response of the river basin and stream network to past and on-going geomorphic and tectonic processes.

\section{Study Area}

The Vamanapuram River, which originates from the southernmost part of the Western Ghats at an elevation above 1,800 $\mathrm{m}$ (Chemmunji Mottai) and flows through the rolling midland and flat plains before finally debouching in the Arabian Sea through the Anjuthengu lake, was selected for the present study. The Vamanapuram River with a flow length of $88 \mathrm{~km}$ drains a total area of $767 \mathrm{~km}^{2}$ in an elongated basin bounded between the north latitudes $8^{\circ} 35^{\prime} 33^{\prime \prime}$ to $8^{\circ} 49^{\prime} 30^{\prime \prime}$ and east longitudes $76^{\circ} 43^{\prime} 15^{\prime \prime}$ to $77^{\circ} 12^{\prime} 34^{\prime \prime}$ (Fig. 1). The

Fig. 1

Location map showing drainages and elevation of the river basin

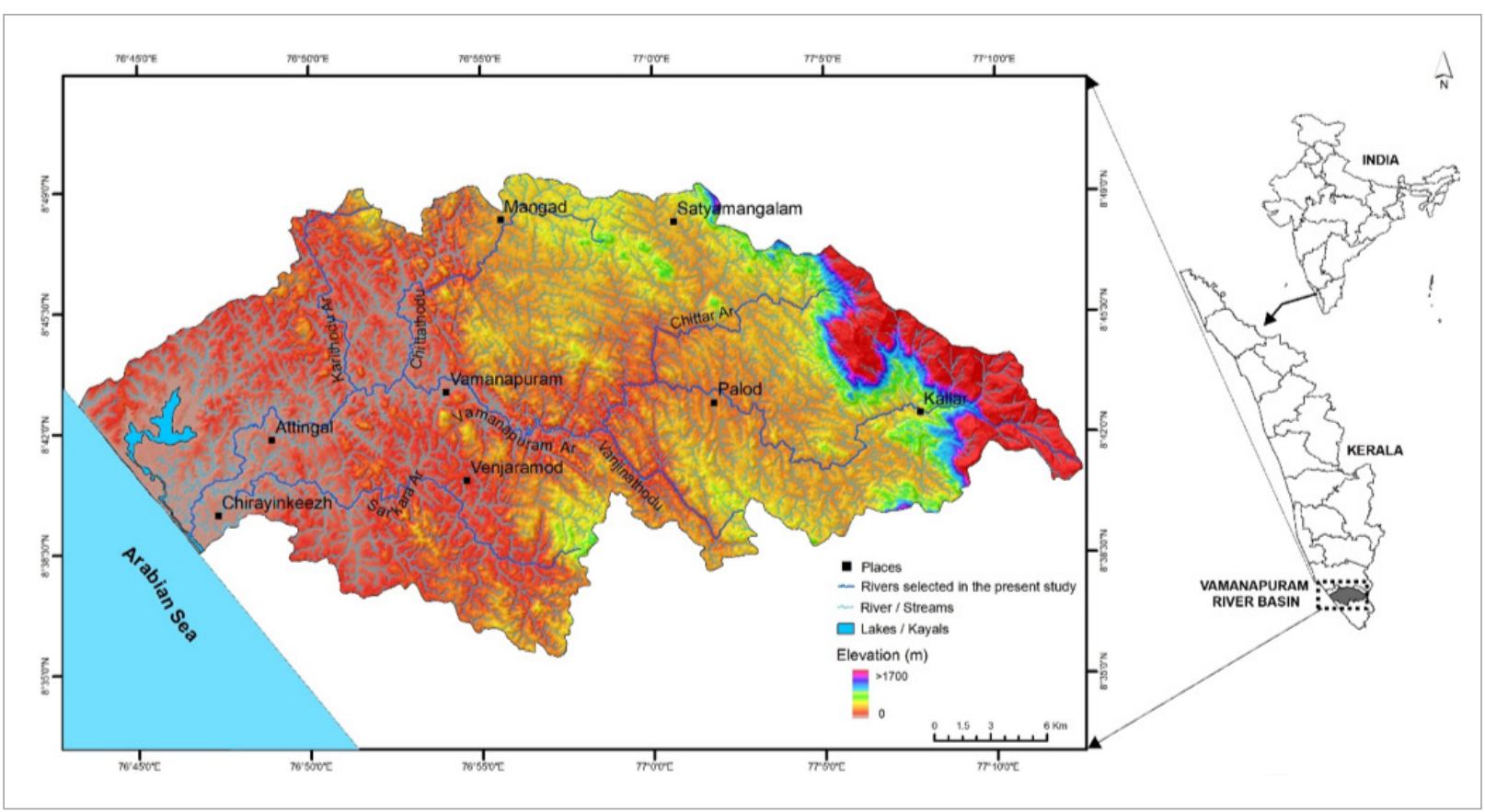


characteristic feature of the watershed is the distinct geomorphology developed over the Precambrian rocks which were subjected to polyphase deformation and metamorphism (Drury et al., 1984). The distinct geomorphological features present in the area vary from denuded high elevated structural hills, residual hills and mounds, valley fills, floodplains and finally to the coastal stretch. Major rocks present in the area are garnet-biotite gneiss, charnockite/charnockite gneiss, pyroxene granulite, garnet-biotite-sillimanite gneiss, quartzo-feldspathic gneiss, and sedimentary formations containing pebble beds, sandstone and clay with lignite intercalations and beach sands. A few earthquake events with lower magnitudes have indicted the change in the equilibrium condition of the region (CESS 2009). The watershed experiences tropical humid climate and two monsoons, namely South-West and North-East, together contributing annual average rainfall above $2,800 \mathrm{~mm}$. Soil characteristics of the basin vary in relation to the geology and elevation. The region between high altitudes and midland is covered with lateritic soils (forest loam is also present in the higher ranges) whereas the low-lying areas are filled with alluvium. Depending on the sub-aerial relief, the land use/land cover changes from forests (in the high altitude regions) followed by rubber plantations, coconut trees, tapioca and pepper plantations in the midlands to paddy fields and plantain in the low lands.

\section{Materials and Methods}

The present study is intended to explore the capability of the longitudinal profile and stream length gradient $(\mathrm{SL})$ indexes, i.e., $\mathrm{SL}$ index and $\mathrm{SL}$ anomaly index, in detecting the anomalies associated with a smaller size tropical river, which exhibits different terrain and exhumed channel characteristics. In order to evaluate the geomorphic characteristics associated with the stream channels, longitudinal profiles of the streams were derived, the SL indexes were calculated and the stream segments were classified on the basis of different orders of anomalies. Datasets used in the analysis include the Survey of India topographical sheets, a geological map and a digital elevation model downloaded from the USGS website (http://earthexplorer.usgs.gov/). Shuttle Radar Topographic Mission (SRTM) data, available at 1 arc second $(30 \times 30 \mathrm{~m}$ resolution), was also used in the present analysis to derive the elevation plots and hydrological variables such as drainage basin boundary and stream networks. The derived hydrological variables were cross compared with the topographic sheets to assure the accuracy of the datasets and found to be comparable. To process the digital elevation model and to derive the longitudinal profiles as well as SL indexes, the ArcInfo ArcGIS 9.3 and Microsoft Office Excel 2013 were used. Methodologies used to derive the longitudinal profile and to calculate the SL index and the SL anomaly index are detailed below.

The longitudinal profile, the altitude-distance plot of the stream from its origin to the mouth in a regular sampling interval, is capable of representing geometric characteristics of the streambed. The geomorphic evolution stage of a stream can be identified by analysing the shape and pattern of the longitudinal profile because any change in the steady state equilibrium of the basin will reflect in the profile as a change in gradational characteristics (Trevisani et al., 2010; Foster and Kelsey, 2012; Giaconia et al., 2012; Miller et al., 2013; Perron and Royden, 2013; Antón et al., 2012, 2014). A stream flowing through the basin, having a steady state condition, shows a smooth, concave profile, while the changes in the equilibrium will reflect as convexity or a combination of a concave-convex nature. This variation can be due to the effect of geological processes such as an uplift or faulting and lithological changes from hard rock to soft rock or vice versa and changes in erosional characteristics due to variation in discharge (Schumm, 1977). Identification and demarcation of the channel anomalies from gradational characteristics of the streams usually begin with the interpretation of longitudinal profile characteristics of the channel. In the present research, the Vamanapuram River and its major tributaries were divided into unique $250 \mathrm{~m}$ segments for the entire length. Further, using the sample extraction tool in the Spatial Analyst extension of ArcGIS software, elevations corresponding to each segment's centre (middle point) were sampled from the DEM. 
Later, the extracted elevation values corresponding to the distance from stream origin were plotted on a distance-elevation graph to generate longitudinal profiles.

Analysis of the longitudinal profiles reveals changes in the steady state condition of the river channel through variable concavity and knick points. In order to understand the severity of the response of streams to geological processes and lithological changes, Hack (1973) developed a stream length gradient $(\mathrm{SL})$ index by analysing the slope gradient of streams in unit length (Fig. 2). The SL indexes are capable of highlighting a small change in the steady state condition of the stream, represented as longitudinal profile irregularities. The SL index can be calculated using the formula:

$$
\mathrm{SL}=(\Delta \mathrm{H} / \Delta \mathrm{L})^{*} \mathrm{~L}
$$

where $\Delta H=$ change in elevation of the reach; $\Delta \mathrm{L}=$ length of the reach, and $L=$ total length of the channel to the point where the $S L$ index is being calculated upstream to the highest point of the channel.

\section{Fig. 2}

Schematic diagram of SL index calculation (modified after de Araújo Monteiro et al., 2010)

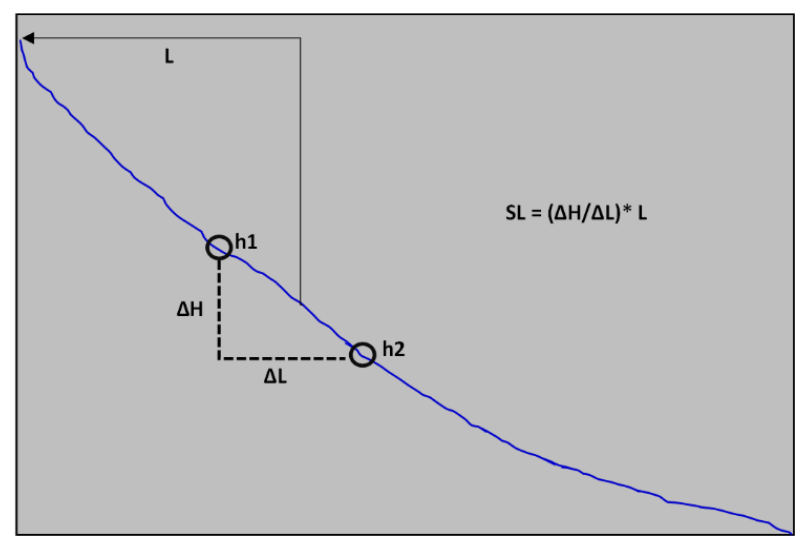

The SL index showing higher values than the neighbouring segments represents the presence of stream bed anomalies as knick points (either as waterfall or rapids), which might have formed due to a sudden change in underlying lithology or faults/uplift of the region in response to the tectonic process (Keller, 1986; Zovoiliet al., 2004; Troiani and Della Seta, 2008; Font et al., 2010; Della Seta et al., 2012; Dar et al., 2014; Doranti-Tiritan et al., 2014).

In order to identify and categorise the anomalies present in the stream channel and differentiate the discontinuities in stream channel morphology on the basis of the order of anomalies, the SL anomaly indices are used. The SL anomaly index can be calculated by dividing the $S L$ index of each stream segment by the $\mathrm{SL}_{\text {total }}$ index of the stream under consideration.

$$
\mathrm{SL} \text { anomaly index }=\mathrm{SL}_{\text {index }} / \mathrm{SL}_{\text {total }}
$$

$\mathrm{SL}_{\text {total }}$ can be derived by dividing the total elevation difference between headwaters and mouth $(\Delta \mathrm{H})$ with the logarithm of the total length ( $\ln L$ ) of the stream under consideration.

The $S L$ anomaly index classifies the stream segments into different orders of anomaly based on the values such as no anomaly ( $\mathrm{SL}$ anomaly $<2$ ), second-order anomaly (SL anomaly $>2$ but $<10$ ) and first-order anomaly (SL anomaly > 10) (Seeber and Gornitz, 1983; de Araújo Monteiro et al., 2010; Martinez et al., 2011; Queiroz et al., 2015). The results of the analysis facilitate the identification of knick points and associated stream characteristics in highly disturbed sections, which are classified as second-order or first-order anomalies. In the present analysis, the stream points used to generate the longitudinal profile and the SL index were taken into account while generating the $\mathrm{SL}$ anomaly indexes.

In the present study, the longitudinal profiles, SL and $S L$ anomaly indexes were generated for the Vamanapuram River and its five major tributaries of various stream orders, namely Chit Ar, Chittar Thodu, Kari Thodu, Vanjina Thodu and Sarkara Ar.

\section{Results and Discussion}

The longitudinal profiles of the Vamanapuram River and its five tributaries, generated from the SRTM digital elevation data, show various shapes and 
structures indicating the differential influence of lithological or geo-environmental process in the region (Fig. 3). Analysis of the longitudinal profile of the Vamanapuram River indicates an overall smooth graded concave profile with minor undulation in the middle and lower reaches (between the flow distance 20-60 km). This might be due to the changes at the base level of the stream caused by the lithological variations or due to change in the already acquired equilibrium condition through tectonic disturbances

Fig. 3

Longitudinal profiles of the streams - (A) Vamanapuram River, (B) Chit Ar, (C) Chittar Thodu, (D) Kari Thodu, (E) Vanjina Thodu and (F) Sarkara Ar

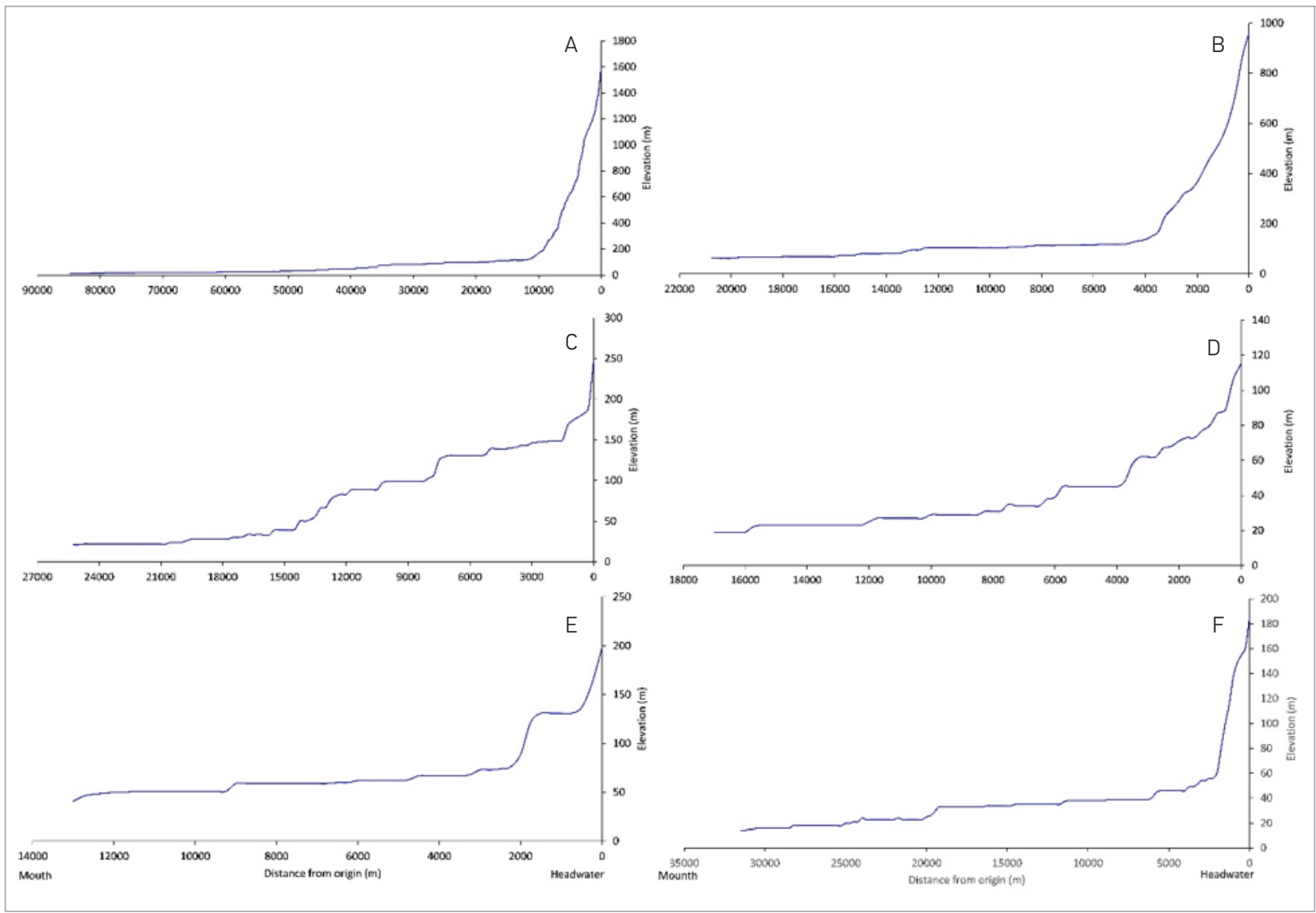

in the region. The longitudinal profiles of major tributaries are discussed in the order of its position, i.e., from the upper catchment region to the lower. The Chit Ar, which flows through the highly undulating hilly terrain, shows a concave profile with convexity in the upper and middle reaches, indicating similar characteristics of the Vamanapuram River. The Chittar Thodu, the major tributary, which flows through the middle elevation reach, shows high variation in the profile. The longitudinal profile of the Chittar Thodu shows stepped appearance in most of its flow length suggesting high disturbances in streambed characteristics. A common pattern of characteristic shapes was observed in the longitudinal profiles of the Kari Thodu, the Vanjina Thodu and the Sarkara Ar, which are comparable with the profile characteristics of the Chittar Thodu. The characteristic pattern in the profile indicates differential response of the stream to the geological characteristics of the streambed or erosional power of the stream. Lithological changes or 
an uplift caused due to the tectonic process might be a reason for the changes in the gradational nature of the profiles. Variation from the smooth concave nature of the streambed characteristics to stepped and convex shoulder characteristics can be considered as knick points, which represent the change in continuity of the normal characteristics of the profile. The variation in the longitudinal profile stated as knick points can be validated by assessing the SL index and the SL anomaly index, which are capable of pointing out the anomalies associated with streambeds and are useful to classify the stream segments based on different orders of magnitude of SL anomaly indexes.
The stream length gradient index (SL index), which represents the gradient variation in unit length of the stream, was used to analyse the channel characteristics formed due to erosion, lithology or tectonic interferences. The SL index values, calculated for the Vamanapuram River and its major tributaries, which show high variation in the segment index, are plotted against the longitudinal profiles of the respective streams for better correlation (Fig. 4). The Vamanapuram River shows changes in the SL index from its origin to the mouth with an undulating nature, with the lowest and highest SL index values of 45 and 1,497 gradient meters. The close examination of the spatial

Fig. 4

The comparative plot showing the stream length gradient index $(S L)$ and the longitudinal profiles of the streams - (A) Vamanapuram river, (B) Chit Ar, (C) Chittar Thodu, (D) Kari Thodu, (E) Vanjina Thodu and (F) Sarkara Ar

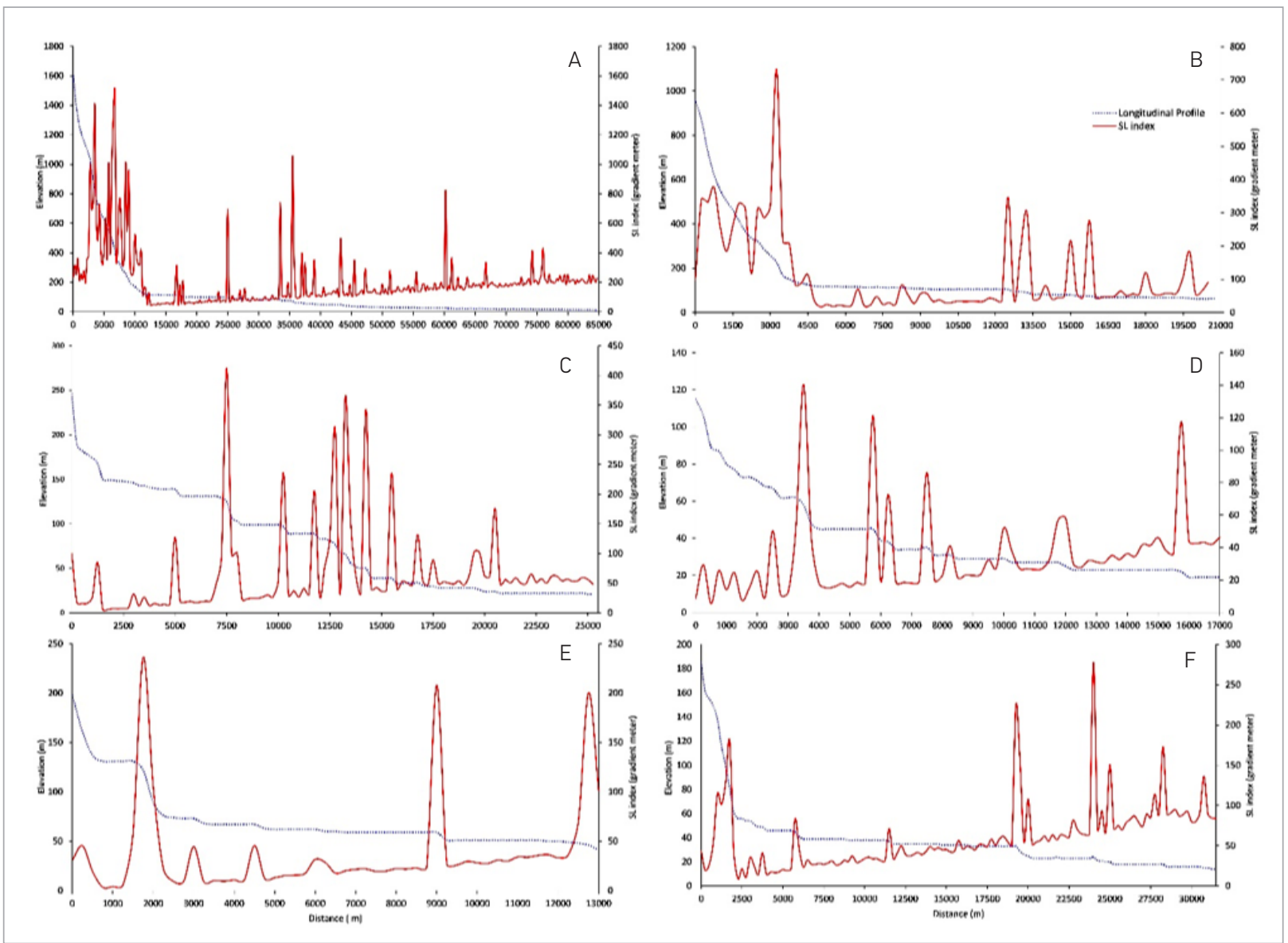


distribution of the SL index generated for the Vamanapuram River indicates more similarity in values than difference, i.e., a higher number of stream segments show more or less similar values. The stream segment with high SL indexes is found to be occurring more in the highland region than in the lower reach of the stream. Compared with the major river, the SL index calculated for each tributary of the Vamanapuram River shows variation in values from its origin to the confluence points. The SL index of the Chit Ar varies from 17 to 731 , indicating higher values in headwater and lower reaches and uniform values in the middle segments. However, in the case of the Chittar Thodu (5-412), the Kari Thodu (5-140), and the Sarkara Ar (9-277), the higher SL indexes are found to be occurring in the lower reaches of the stream, whereas the Vanjina Thodu (3-236) shows almost uniform distribution of SL indexes with three prominent sections of a higher SL index. The graphical representation of the $S L$ index against the longitudinal profiles of the streams facilitates the confirmation of the presence of knick points by exactly crossing the stream segments having variation in profile concavity with higher SL indexes. Abrupt changes in the SL index in adjacent segments of the stream may have been caused by the response of a streambed to spatially variable uplifts, increase of the discharge rate in the downstream reach or change in the direction of stream valleys, or change in a particle size of the gravelly streambed (Keller and Rockwell, 1984; Keller and Pinter, 2002). This might induce a disequilibrium condition in the streambed and result in anomalies in the stream profile.

The assessment of the $\mathrm{SL}$ index and its comparison with the longitudinal profile make it easy to understand and confirm the stream segments and reaches which possess anomalies due to tectonic influences, lithological variations or hydrological characteristics. The calculated SL anomaly index will facilitate the classification of anomalies in the stream channel into different classes, based on the order of magnitudes. The SL anomaly index for the Vamanapuram River and its major tributaries are classified based on the cutoff thresholds corresponding to each anomaly classes and are shown in Fig. 5. It was noted that all the analysed streams contained anomaly and no anomaly segments. The stream segments in no anomaly as well as second-order anomaly classes predominate over those in the first-order anomaly. In the case of the Vamanapuram River, the majority of the stream segments are categorised as no anomaly (SL anomaly index $<2$ ). The segments which show higher order anomalies (mostly second order) in the Vamanapuram River are found to be occurring in the headwater region as cluster and are sparsely distributed in the middle and lower reaches. Similar characteristics were also noticed in the Chit Ar, which shows very few higher order (second order) anomaly segments. At the same time, the Chittar Thodu, the Kari Thodu, the Vanjina Thodu and the Sarkara Ar show presence of the first-order anomalies in the stream segments indicating a higher degree of terrain disturbances. In the Chittar Thodu, the majority of the segments fall in higher order anomalies (second order and a few of first order), and are found to be occurring after a few kilometres from the origin point. The Kari Thodu also shows the same pattern in which the order of anomalies is found to be increasing towards the lower reach of the stream. Among the tributaries, the Vanjina Thodu shows a distinct pattern with most segments coming under no anomaly class and a few segments with first order anomalies. SL anomalies present in the Sarkara Ar show a gradual increase in higher order anomalies after the middle reach of the stream, attaining the maximum at the lower reach. Compared with the Vamanapuram River, the higher order anomalies are found to be more frequent in the tributaries, especially in the Kari Thodu, the Chittar Thodu and the Sarkara Ar. The presence of higher order SL anomalies in the stream segments coincides with the knick points identified in the longitudinal profiles and confirmed by the SL indexes, represented as stepped or convex profile segments suggesting lithological or tectonic disturbances in the region.

Spatial variation in channel anomalies, in terms of different orders of the SL anomaly index, can be accounted to the geological features such as lithological variations and structural features present in the study area. The influence of lithology/structures was 
Fig. 5

The SL anomaly index showing different order of anomalies present in the streams - (A) Vamanapuram River, (B) Chit Ar, (C) Chittar Thodu, (D) Kari Thodu, (E) Vanjina Thodu and (F) Sarkara Ar
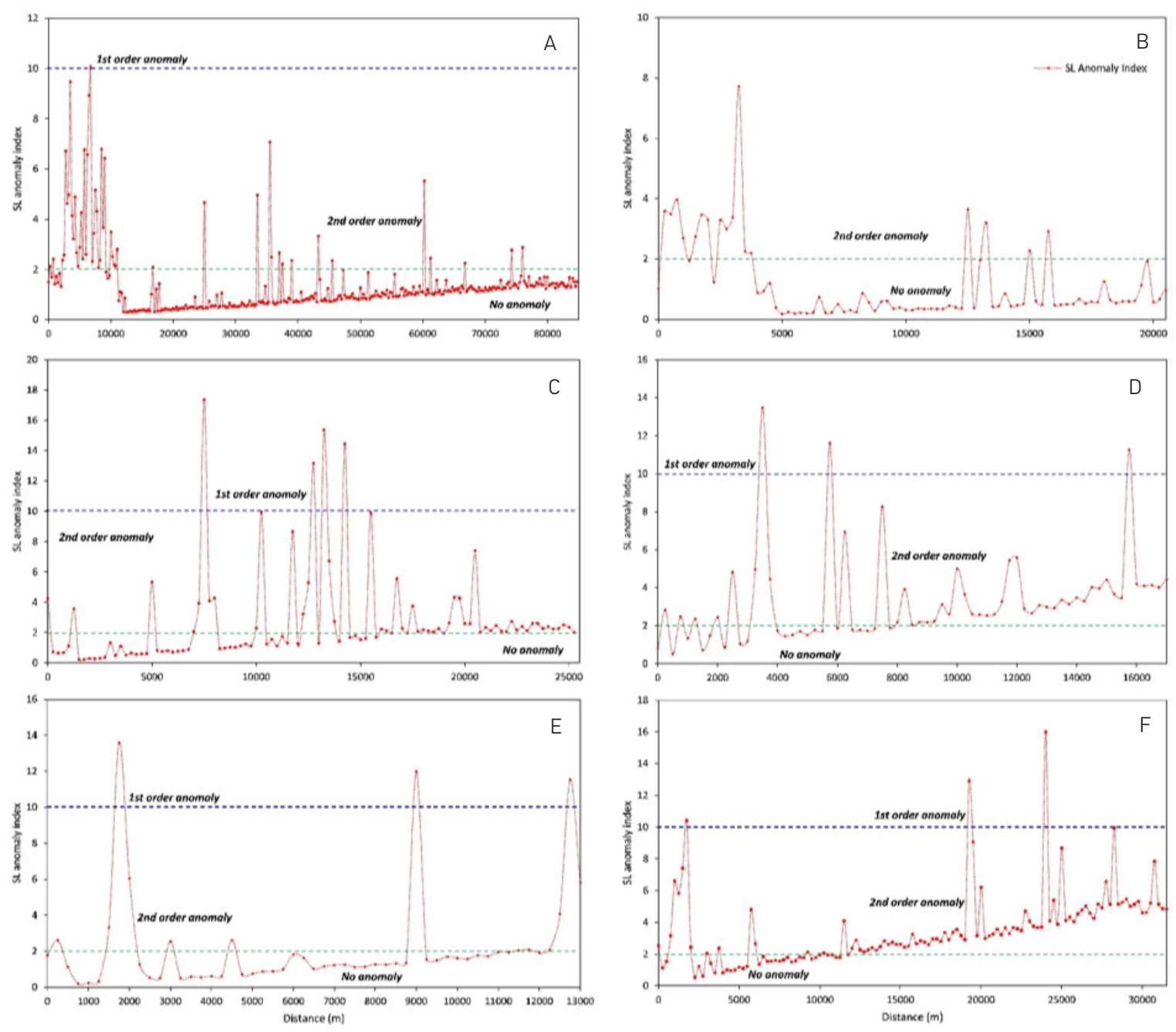

validated through overlaying the SL anomaly index points on the geological map of the river basin extracted from the regional geological map (GSI 1995). It is significant to note that the regional scale map could not convey the real field characteristics due to scale limitations. Though the study area possesses different lithology and is cross cut by the rivers in the region, the higher order (second order and above) stream anomalies are found to be occurring in uniform lithology rather than in the contact zones (Fig. 6). It is also noted that the structural features, already identified and mapped from the river basin, do not show a direct influence on the stream anomalies characterised in the present study. However, the geological formation in the region has undergone polyphase deformation, which might have a direct influence on the stream channel characteristics in the region (Drury et al., 1984). Findings and inferences of the present study confirm the influence of tectonic process over the stream anomalies rather than the normal denudational processes. This 
Fig. 6

Cross comparison of SL anomaly classes with lithology, structure and reported earthquake epicentres in the drainage basin

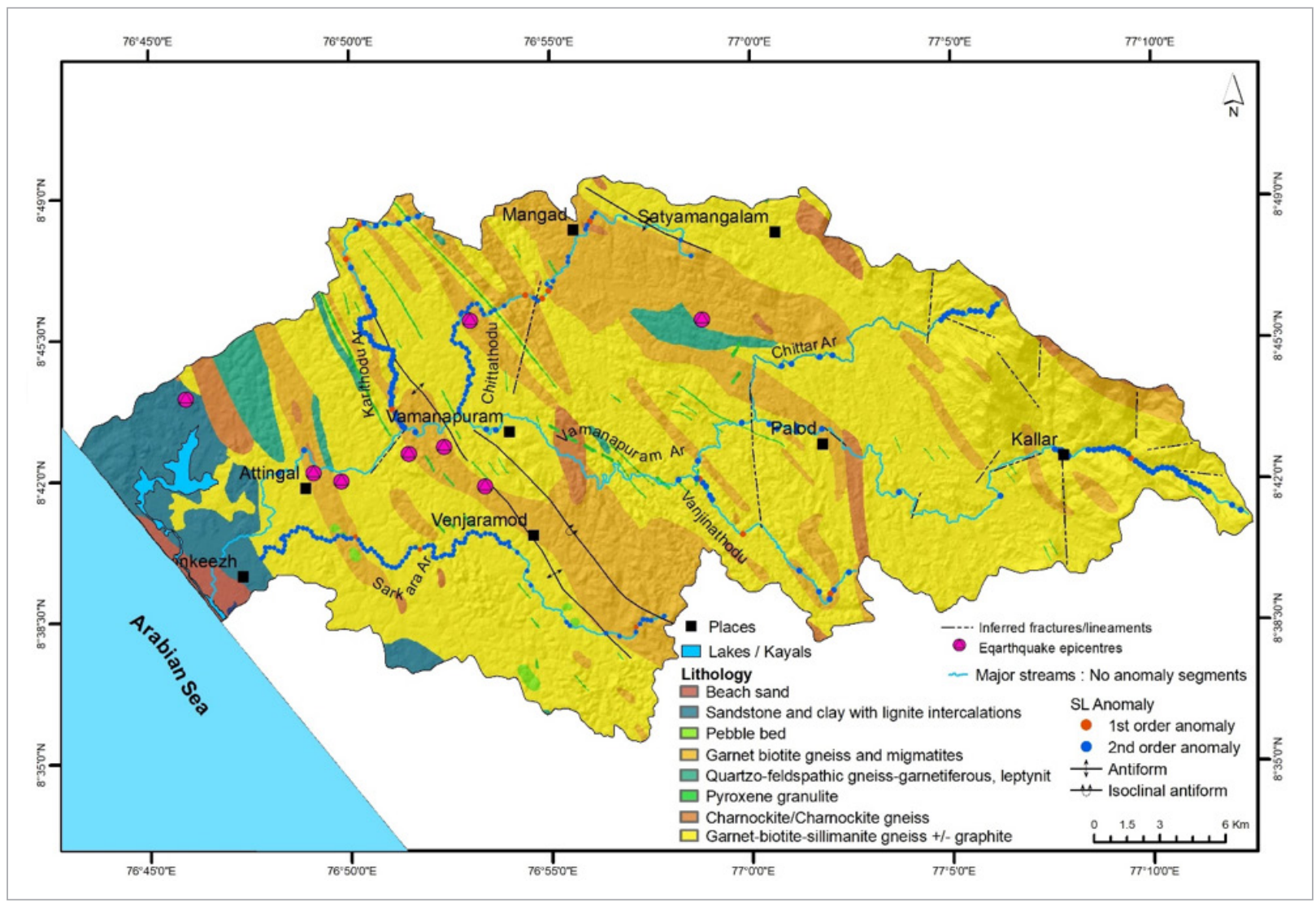

can be supplemented by the repeated occurrence of earthquakes of varying magnitudes in the Vamanapuram River basin. The study area has witnessed a few earthquakes with magnitudes varying between $<3$ to $>4 \mathrm{M}$ in the recent past, indicating the activation or reactivation of the structural features, mainly faults and fractures, which can be considered as the evidence of the neotectonic process in the region. A study conducted by Valdia and Narayana (2007) in six south Kerala rivers confirms the control of neotectonic activity over the stream characteristics due to the vertical and horizontal movement of regional as well as local faults, trending NNE-SSW, N-S and WNW-ESE, present in the late Quaternary period. The hypsometric characterisation of the Vamanapuram River basin, carried out by Chattopadhyay et al. (2006), suggests a differential influence of a tectonic uplift in the midland regions, which resulted in different geomorphic characteristics of the streams. However, the study area warrants detailed mapping of structural features especially in the stream segments which are marked as anomalous.

\section{Conclusion}

The longitudinal profiles of the Vamanapuram River and its five major tributaries show a varying nature of gradation (deviation from concavity) in different lengths of the stream segments, representing the knick points present in the channels. The presence of these variations was validated through the generation and interpretation of the SL index, which shows high variation in nearby segments corresponding to the knick points present in the longitudinal profiles. 
The classification of stream anomalies based on the $\mathrm{SL}$ anomaly index facilitated the division of stream segments into two categories such as stream segments with anomaly and no anomaly. This classification points out that the Vamanapuram River is less anomalous, whereas the tributaries contain higher numbers of anomalous segments, especially the Kari Thodu, the Chittar Thodu and the Sarkara Ar.

The anomalous stream segments are spatially distributed in uniform lithology, mainly of hard crystalline rocks, and have no direct correlation with the regional structural features (folds) of the region. This points towards the differential influence of geological processes operated in the region over the stream characteristics, which include the response of rocks to a tectonic uplift and consequent erosion. The suggested presence of neotectonic activity is supplemented by the repeated occurrence of low magnitude earthquakes in the region, especially in the study area. The study highlights that the analysis of a longitudinal profile of the stream, in conjunction with the SL index and the SL anomaly index, will be helpful to reveal the geomorphological impact of different geological processes over the stream networks.

\section{References}

Ahmad S., Bhat M.I., Madden C., et al., (2014). Geomorphic analysis reveals active tectonic deformation on the eastern flank of the PirPanjal Range, Kashmir Valley, India. Arabian J ournal of Geoscience. 7(6): 2225-2235. https://doi.org/10.1007/s12517013-0900-y

Ajibade L.T., Ifabiyi L.P., Iroye K.A. et al., (2010). Morphometric analysis of Ogunpa and Ogbere drainage basins, Ibadan, Nigeria. Ethiopian Journal of Environmental Studies and Management. 3(1):13-19. https://doi.org/10.4314/ejesm.v3i1.54392

Ajin R.S., Krishnamurthy, R.R., Jayaprakash M., et al., (2013). Flood hazard assessment of vamanapuram river basin, Kerala, India: An approach using remote sensing \& GIS techniques. Advances in Applied Scientific Research. 4(3): 263-274.

Antón L., Rodés A., De Vicente G., et al., (2012). Quantification of fluvial incision in the Duero Basin (NW Iberia) from longitudinal profile analysis and terrestrial cosmogenic nuclide concentrations. Geomorphology.165: 50-61. https://doi.org/10.1016/j. geomorph.2011.12.036

Antón L., De Vicente G., Muñoz-Martín A., et al., (2014). Using river long profiles and geomorphic indices to evaluate the geomorphological signature of continental scale drainage capture, Duero basin (NW Iberia). Geomorphology. 206: 250-261. https://doi.org/10.1016/j.geomorph.2013.09.028

Aram Z., Arian M. (2016). Active tectonics of the Gharasu river basin in Zagros, Iran, investigated by calculation of geomorphic indices and group decision using analytic hierarchy process (AHP) software. Episodes. 39(1): 39-44. https://doi. org/10.18814/epiiugs/2016/v39i1/89235

Bhat F.A., Bhat I.M., Sana H., et al., (2013). Identification of geomorphic signatures of active tectonics in the West Lidder Wa- tershed, Kashmir Himalayas: Using Remote Sensing and GIS. International Journal of Geomorphology and Geoscience. 4(1): 164-176.

Bhattacharjee D., Jain V., Chattopadhyay A., et al., (2016). Geomorphic evidences and chronology of multiple neotectonic events in a cratonic area: results from the Gavilgarh Fault Zone, central India. Tectonophysics. 677: 199-217. https://doi. org/10.1016/j.tecto.2016.04.022

Biswas S., Sudhakar S., Desai V.R. (1999). Prioritisation of subwatersheds based on morphometric analysis of drainage basin: A remote sensing and GIS approach. Journal of the Indian Society of Remote Sensing. 27(3): 155-166. https://doi. org/10.1007/BF02991569

Borgohain S., Das J., Saraf A.K. et al., (2016). Morphodynamic changes of Lohit River, NE India: GIS-based study. Current Science. 110(9): 1810.

CESS. (2009). Natural Hazard Zonation of Map of Kerala. Thiruvananthapuram, India: Centre for Earth Science Studies, Govt. of Kerala.

Chang Z., Sun W., Wang J. (2015). Assessment of the relative tectonic activity in the Bailongjiang Basin: insights from DEM-derived geomorphic indices. Environmental Earth Science. 74(6): 5143-5153. https://doi.org/10.1007/s12665-0154525-1

Chattopadhyay S., Kumar S.S., Chattopadhyay M. (2006). Landscape evolution in parts of Varnanapuram drainage basin, Kerala-a hypsometric approach. Journal of Geological Society of India 68(5): 841-856.

Cheng W., Wang N., Zhao M., et al., (2016). Relative tectonics and debris flow hazards in the Beijing mountain area from 
DEM-derived geomorphic indices and drainage analysis. Geomorphology. 257: 134-142. https://doi.org/10.1016/j.geomorph.2016.01.003

Dar R.A., Romshoo S.A., Chandra R., et al., (2014). Tectono-geomorphic study of the Karewa Basin of Kashmir Valley. Journal of Asian Earth Science.92: 143-156. https://doi.org/10.1016/j. jseaes.2014.06.018

Dehbozorgi M., Pourkermani M., Arian M., et al., (2010). Quantitative analysis of relative tectonic activity in the Sarvestan area, central Zagros, Iran. Geomorphology. 121(3): 329-341. https:// doi.org/10.1016/j.geomorph.2010.05.002

Della Seta M., Galve J.P., Piacentini D., et al., (2012). Computation, validation and sensitivity of the DTM-derived geomorphic parameters: the case of Stream-Length Gradient Index. In EGU General Assembly Conference Abstracts. (Vol. 14, p. 4636).

deAraújo Monteiro K., Missura R., de Barros Correa, A.C. (2010). Application of the Hack index-or stream length-gradient index (SL index)-to the Tracunhaém river watershed, Pernambuco, Brazil. Geociências. 29(4):533-539

Dhont D., Chorowicz J. (2006). Review of the neotectonics of the Eastern Turkish-Armenian Plateau by geomorphic analysis of digital elevation model imagery. International Journal of Earth Science. 95(1), 34-49. https://doi.org/10.1007/s00531-005-0020-3

Doranti-Tiritan C., Hackspacher P.C., de Souza D.H., et al., (2014). The use of the stream length-gradient index in morphotectonic analysis of drainage basins in Poços de Caldas Plateau, SE Brazil. International Journal of Geoscience. 5(11): 1383. https://doi. org/10.4236/ijg.2014.511112

Drury S.A., Harris N.B.W., Holt R.W., et al., (1984). Precambrian tectonics and crustal evolution in South India. The Journal of Geology. 92:3-20. https://doi.org/10.1086/628831

Figueroa A.M., Knott J.R. (2010). Tectonic geomorphology of the southern Sierra Nevada Mountains (California): Evidence for uplift and basin formation. Geomorphology. 123(1): 34-45. https://doi.org/10.1016/j.geomorph.2010.06.009

Font M., Amorese D., Lagarde J.L. (2010). DEM and GIS analysis of the stream gradient index to evaluate effects of tectonics: the Normandy intraplate area (NW France). Geomorphology. 119(3): 172-180. https://doi.org/10.1016/j.geomorph.2010.03.017

Foster M.A., Kelsey H.M. (2012). Knickpoint and knickzone formation and propagation, South Fork Eel River, northern California. Geosphere. 8(2): 403-416. https://doi.org/10.1130/ GES00700.1

Giaconia F., Booth-Rea G., Martínez-Martínez J.M., et al., (2012). Geomorphic evidence of active tectonics in the Sierra Alhamilla (eastern Betics, SE Spain). Geomorphology. 145-146:90-106. https://doi.org/10.1016/j.geomorph.2011.12.043
GSI. (1995). Geological and Mineral Map of Kerala. Kolkata, India: Geological Survey of India, Govt. of India, Ministry of Mines Hack J.T. (1973). Stream-profile analysis and stream-gradient index. U.S. Geological Survey Journal of Research. 1: 421-429.

Horton R.E. (1932). Drainage basin characteristics. Transactions of American Geophysical Union. 13:350-361. https://doi. org/10.1029/TR013i001p00350

Horton R.E. (1945). Erosional development of streams and their drainage basins: hydrophysical approach to quantitative morphology. Bulletin Geological Society of America. 56:275-370 https://doi.org/10.1130/0016-7606(1945)56[275:EDOSAT]2.0.C0;2

Joji V.S., Nair A.S.K., Changat M. (2001). Morphometric analysis of fourth order sub-basins of Vamanapuram river basin, Southern Kerala, India. The Indian Journal of Geomorphology. 6: 59-74.

Joji V.S., Nair A.S.K. (2014). Terrain characteristics and longitudinal, land use and land cover profiles behavior-a case study from Vamanapuram river basin, southern Kerala, India. Arabian Journal of Geosciences. 7(4): 1351-1361. https://doi. org/10.1007/s12517-012-0815-z

Joshi P.N., Maurya D.M., Chamyal L.S. (2013). Morphotectonic segmentation and spatial variability of neotectonic activity along the Narmada-Son Fault, Western India: Remote sensing and GIS analysis. Geomorphology. 180: 292-306. https://doi. org/10.1016/j.geomorph.2012.10.023

Kale V.S., Shejwalkar N. (2008). Uplift along the western margin of the Deccan Basalt Province: Is there any geomorphometric evidence?. Journal of Earth System Science. 117(6): 959-971. https://doi.org/10.1007/s12040-008-0081-3

Kale V.S., Sengupta S., Achyuthan H., et al., (2014). Tectonic controls upon Kaveri River drainage, cratonic Peninsular India: Inferences from longitudinal profiles, morphotectonic indices, hanging valleys and fluvial records. Geomorphology. 227: 153165. https://doi.org/10.1016/j.geomorph.2013.07.027

Keller E.A. (1986). Investigation of active tectonics: use of surficial earth processes. Active Tectonics. National Academy Press, Washington D.C.

Keller E.A., Pinter N. (2002). Active tectonics. Earthquakes, Uplift, and Landscape. Prentice Hall, New Jersey. pp362.

Kothyari G.C., Rastogi B.K., Morthekai P., et al., (2016). Active segmentation assessment of the tectonically active South Wagad Fault in Kachchh, Western Peninsular India. Geomorphology. 253: 491-507. https://doi.org/10.1016/j.geomorph.2015.10.029

Mahmood S.A., Gloaguen R. (2012). Appraisal of active tectonics in Hindu Kush: Insights from DEM derived geomorphic indices and drainage analysis. Geoscience Frontiers. 3(4): 407-428. https://doi.org/10.1016/j.gsf.2011.12.002 
Malik M.I., Bhat M.S., Kuchay N.A. (2011). Watershed based drainage morphometric analysis of Lidder catchment in Kashmir valley using geographical information system. Recent Research in Science and Technology. 3(4):118-126.

Martinez M., Hayakawa E.H.,Stevaux J.C., et al., (2011). SL index as indicator of anomalies in the longitudinal profile of Pirapó River. Geociências (São Paulo). 30(1): 63-76.

Matoš B., Pérez-Peña J.V., Tomljenović B. (2016). Landscape response to recent tectonic deformation in the SW Pannonian Basin: Evidence from DEM-based morphometric analysis of the Bilogora Mt. area, NE Croatia. Geomorphology. 263:132-155. https://doi.org/10.1016/j.geomorph.2016.03.020

Mesa L.M. (2006). Morphometric analysis of a subtropical Andean basin (Tucuman, Argentina). Environmental Geology. 50(8):1235-1242. https://doi.org/10.1007/s00254-006-0297-y

Miller V.C. (1953). A quantitative geomorphic study of drainage basin characteristics in the Clinch Mountain area, Virginia and Tennessee, Proj. NR 389-402, Tech. Rep. 3. Columbia University, Department of Geology, ONR, New York

Miller S.R., Sak P.B., Kirby E., et al., (2013). Neogene rejuvenation of central Appalachian topography: Evidence for differential rock uplift from stream profiles and erosion rates. Earth and Plane Science Letters. 369: 1-12. https://doi.org/10.1016/j. epsl.2013.04.007

Moussi A., Rebaï N., Chaieb A., et al., (2018). GIS-based analysis of the Stream Length-Gradient Index for evaluating effects of active tectonics: a case study of Enfidha (North-East of Tunisia). Arabian Journal of Geosciences, 11(6), 123. https://doi. org/10.1007/s12517-018-3466-x

Nag S.K. (1998). Morphometric analysis using remote sensing techniques in the Chaka sub-basin, Purulia district, West Bengal. Journal of the Indian Society of Remote Sensing. 26(1-2): 69-76. https://doi.org/10.1007/BF03007341

Ntokos D., Lykoudi E., Rondoyanni T. (2016). Geomorphic analysis in areas of low-rate neotectonic deformation: South Epirus (Greece) as a case study. Geomorphology. 263: 156-169. https://doi.org/10.1016/j.geomorph.2016.04.005

Pedrera A., Pérez-Peña J.V., Galindo-Zaldívar J., et al., (2009). Testing the sensitivity of geomorphic indices in areas of lowrate active folding (eastern Betic Cordillera, Spain). Geomorphology. 105(3): 218-231. https://doi.org/10.1016/j.geomorph.2008.09.026

Perron J.T., Royden L. (2013). An integral approach to bedrock river profile analysis. Earth Surface Processes and Landforms. 38(6): 570-576. https://doi.org/10.1002/esp.3302

Pérez-Peña J.V., Azor A., Azañón J.M. et al., (2010). Active tectonics in the Sierra Nevada (Betic Cordillera, SE Spain): in- sights from geomorphic indexes and drainage pattern analysis. Geomorphology. 119(1): 74-87. https://doi.org/10.1016/j.geomorph.2010.02.020

Prizomwala S.P., Solanki T., Chauhan G. et al., (2016). Spatial variations in tectonic activity along the Kachchh Mainland Fault, Kachchh, western India: implications in seismic hazard assessment. Natural Hazards. 82(2): 947-961. https://doi. org/10.1007/s11069-016-2228-x

Queiroz G.L., Salamuni E., Nascimento E.R. (2015). Knickpoint finder: A software tool that improves neotectonic analysis. Computers \& Geoscience. 76: 80-87. https://doi.org/10.1016/j. cageo.2014.11.004

Roy S., Sahu A.S. (2015). Quaternary tectonic control on channel morphology over sedimentary low land: a case study in the Ajay-Damodar interfluve of Eastern India. Geoscience Frontiers. 6(6):927-946. https://doi.org/10.1016/j.gsf.2015.04.001

Schumm S.A. (1956). Evolution of drainage systems and slopes in badlands at Perth Amboy, New Jersey. Bulletin Geological Society of America. 67:597-646. https://doi.org/10.1130/0016 -7606(1956)67[597:EODSAS]2.0.C0;2

Schumm S.A. (1963). Sinuosity of alluvial rivers on the Great Plains. Bulletin Geological Society of America. 74:1089-1100. https://doi. org/10.1130/0016-7606(1963)74[1089:SOAROT]2.0.CO;2

Schumm S.A. (1977).The fluvial system (Vol. 338). New York: Wiley.

Seeber L., Gornitz V.M. (1983). River profiles along the Himalayan arc as indicators of active tectonics. Tectonophysics. 92:335-367. https://doi.org/10.1016/0040-1951(83)90201-9

Singh P., Thakur J.K., Singh U.C. (2013). Morphometric analysis of Morar River Basin, Madhya Pradesh, India, using remote sensing and GIS techniques. Environmental Earth Science. 68(7): 1967-1977. https://doi.org/10.1007/s12665-012-1884-8

Strahler A.N. (1952). Hypsometric (area altitude) analysis of erosional topography. Bulletin of Geological Society of America. 63:1117-1142. https://doi.org/10.1130/0016-7606(1952)63 [1117:HAAOET]2.0.CO;2

Strahler A.N. (1957). Quantitative analysis of watershed geomorphology. Transactions of American Geophysical Union. 38:913-920. https://doi.org/10.1029/TR038i006p00913

Strahler A.N. (1964). Quantitative geomorphology of drainage basins and channel networks. In: Chow VT (ed) Handbook of applied hydrology. McGraw Hill, New York, Section 4-11

Trevisani S., Cavalli M., Marchi L. (2010). Reading the bed morphology of a mountain stream: a geomorphometric study on high-resolution topographic data. Hydrology and Earth System Sciences. 14: 393-405. https://doi.org/10.5194/hess-14-3932010 
Troiani F., DellaSeta M. (2008). The use of the Stream Length-Gradient index in morphotectonic analysis of small catchments: $A$ case study from Central Italy. Geomorphology. 102(1): 159-168. https://doi.org/10.1016/j.geomorph.2007.06.020

Sujatha E.R., Selvakumar R., Rajasimman U.A.B. et al., (2015). Morphometric analysis of sub-watershed in parts of Western Ghats, South India using ASTER DEM. Geomatics Natural Hazards and Risk. 6(4): 326-341. https://doi.org/10.1080/1947570 5.2013 .845114

Valdiya K.S., Narayana A.C. (2007). River response to neotectonic activity: Example from Kerala, India. Journal of Geological Society of India. 70(3):427-443.

Vijith H., Prasannakumar V., Pratheesh P. et al., (2016) Evaluation of geomorphic expressions of bedrock Channels in the Western Ghats of southern Kerala, India, through quantitative analysis. Arabian Journal of Geosciences. 9(5): 1-15. https:// doi.org/10.1007/s12517-016-2401-2

Viveen W., Van Balen R.T., Schoorl J.M. et al., (2012). Assessment of recent tectonic activity on the NW Iberian Atlantic Margin by means of geomorphic indices and field studies of the Lower Miño River terraces. Tectonophysics. 544: 13-30. https:// doi.org/10.1016/j.tecto.2012.03.029

Yunus A.P., Oguchi T., Hayakawa Y.S. (2014). Morphometric analysis of drainage basins in the Western Arabian Peninsula using multivariate statistics. International Journal of Geoscience. 5(5). https://doi.org/10.4236/ijg.2014.55049

Zovoili E., Konstantinidi E., Koukouvelas I.K. (2004). Tectonic geomorphology of escarpments: the cases of Kompotades and NeaAnchialos faults. Bull of the Geological Society of Greece. 36(5): 1716-1725. https://doi.org/10.12681/bgsg.16579 